\title{
Maciej Soin
}

Lodz University of Technology

Faculty of Management and Production Engineering

Institute of Social Sciences and Management of Technologies

e-mail: maciej.soin@p.lodz.pl

\section{CSR i etyka przekonań}

\section{CSR and the ethics of conviction}

Examples of scandals related to exposing the unethical practices of companies which are classified as CSR leaders include cases where their declarations on undertaking social responsibility, as well as spending a lot of money on spectacular social campaigns and then rigorously reporting it in the appropriate documents, are accompanied by acts of abusing workers' and environmental rights, misleading customers, i.e., abusing consumer rights, and finally "tax optimisation", which generates measurable losses to the local communities. These cases raise the question about the reason for corporate social responsibility not being immune to abuse or opportunities to treat it as merely an image-related issue.

The problem is presented using Max Weber's widely known typology. It contrasts the ethics of conviction (ruled by the principle of intentionally keeping to the rules which have been adopted as being right) with the ethics of responsibility for the consequences of actions, including those that were undertaken in good faith but which have unintentional consequences. The usefulness of Weber's typology when considering CSR problems becomes evident when we notice that the dominant interpretation of the corporate social responsibility concept, with its characteristic emphasis on voluntariness and positivity of actions within CSR, brings this concept closer to the ethics of conviction model. Voluntary actions in the field of CSR should go beyond carrying out regular goals of economic activities, i.e., the maximisation of profits, by providing good quality, desirable goods and services. However, what should be considered a prosocial activity - and thus, social responsibility - remains unclear in some companies.

In accordance with the thesis of the paper, this ambiguity is one of the important factors that create discrepancies between declarations and real corporate activities. As we can see, the focus on voluntarily doing good which has been 
adopted in the current interpretation of CSR pre-empts the pursuit to avoid bad practices, both in theory and in the implementation of CSR programmes. Moreover, the CSR-dominant interpretation leads to a particular terminological confusion and replaces the companies' responsibility towards concrete stakeholders, which is appropriate for the economic activity, with an abstractly understood responsibility towards an abstractly understood society. In this sense, the conceptual analysis of the relationship between CSR and ethics reveals that one of the important sources of problems with CSR is joining this concept with an unsuitable model of ethics. This is not because of the alleged defects of the ethics of conviction, appreciated by Weber, among other thinkers, but because it is a model that, in fact, is not suitable for business ethics. If the ethics of conviction is private, then it cannot be used to regulate social relations.

In conclusion, it may be stated that, paradoxically, a dominant way of thinking about the social responsibility of corporations leads more to separation than to bringing together ethics and business. CSR, in its current form, cannot be an efficient means of implementing ethical objectives in business because it defines the issue of social responsibility as a sphere of private beliefs and arbitrary interpretations. Therefore, it undermines the relevance of the proper and socially significant notion of responsibility for economic activities and their consequences. Of course, the CSR concept can and should be modified; the question remains as to whether eliminating the elements that bring it closer to the ethics of conviction does not actually translate into giving it up entirely.

Keywords: CSR, ethics of conviction, ethics of responsibility, Max Weber

JEL Classification: M14, Z13

\section{Problem i teza}

Przykłady skandali związanych z ujawnieniem nieetycznych działań firm zaliczanych do liderów CSR obejmują przypadki, w których deklaracjom o podejmowaniu społecznej odpowiedzialności, a także przeznaczaniu dużych środków na spektakularne akcje społeczne i ich skrupulatnym wykazywaniu w stosownych raportach, towarzyszą praktyki łamania praw pracowniczych i środowiskowych, wprowadzania klientów w błąd, zatem łamania praw konsumenckich, a wreszcie „optymalizacji podatkowej”, przynoszącej wymierne straty społecznościom lokalnym (cf. m.in.: Jahdi \& Acikdilli, 2009; Sikka, 2010; Fassin \& Buelens, 2011). Przypadki te skłaniają do postawienia pytania o źródła małej odporności koncepcji społecznej odpowiedzialności przedsiębiorstw na nadużycia i okoliczności sprzyjające traktowaniu jej postulatów jako kwestii czysto wizerunkowej.

Wykorzystany w artykule sposób postawienia tak zarysowanego problemu nawiązuje do znanej typologii Maksa Webera, kontrastującej etykę przekonań 
kierowaną przez regułę intencjonalnej wierności zasadom uznanym za słuszne i etykę odpowiedzialności za następstwa działań, również tych, które zostały podjęte $\mathrm{z}$ dobrą wolą i przekonaniem, a przyniosły niezamierzone konsekwencje. Przydatność typologii Webera do rozważenia problemów CSR ujawnia się wówczas, gdy zauważymy, że dominująca wykładnia koncepcji społecznej odpowiedzialności przedsiębiorstw wraz z charakterystycznym dla niej akcentem na dobrowolność i pozytywność działań w zakresie CSR zbliża tę koncepcję do modelu etyki przekonań. Dobrowolne działania w zakresie CSR mają zatem wykraczać poza realizację zwykłych celów działań gospodarczych, to znaczy maksymalizację zysków przez dostarczanie pożądanych towarów i usług odpowiedniej jakości. Co jednak zostanie uznane za działanie prospołeczne - a także za społeczną odpowiedzialność - pozostaje niejasną kwestią decyzji poszczególnych firm, względnie organizacji sporządzających rankingi i zestawienia z zakresu CSR.

Zgodnie z tezą artykułu okoliczność ta należy do ważnych czynników sprzyjających rozbieżności między deklaracjami i rzeczywistymi działaniami przedsiębiorstw. Jak bowiem zauważono, przyjęta w obiegowej wykładni CSR koncentracja na dobrowolnym czynieniu dobra (doing good) wypiera dążenie do unikania złych praktyk (avoiding bad) zarówno w teoriach, jak i w zastosowaniach programów CSR (cf. Lin-Hi \& Müller, 2013). Co więcej, dominująca wykładnia CSR prowadzi do szczególnego zamieszania pojęciowego, zastępując właściwą dla sfery działalności gospodarczej odpowiedzialność firm wobec skonkretyzowanych interesariuszy przez abstrakcyjnie rozumianą odpowiedzialność wobec abstrakcyjnie rozumianego społeczeństwa. W tym sensie pojęciowa analiza związków CSR i etyki przekonań wskazuje, że jednym z ważnych źródeł notorycznych kłopotów z CSR jest związanie tej koncepcji z niewłaściwym modelem etyki. Nie ze względu na domniemane wady etyki przekonań, docenianej wszak również przez Webera, ale dlatego, że jest to model, który nie nadaje się do wykorzystania w dziedzinie etyki biznesu. Jeśli etyka przekonań ma charakter prywatny, to nie nadaje się do regulacji stosunków społecznych.

W konkluzji można zatem stwierdzić, że - paradoksalnie - dominujący sposób myślenia o społecznej odpowiedzialności przedsiębiorstw prowadzi raczej do separacji niż do powiązania etyki i biznesu. CSR w obecnej postaci nie może być efektywnym środkiem implementacji postulatów etycznych w biznesie, ponieważ kwestię społecznej odpowiedzialności uznaje za dziedzinę prywatnych przekonań i arbitralnych interpretacji. Tym samym pomniejsza znaczenie właściwego i społecznie istotnego pojęcia odpowiedzialności za działania gospodarcze i ich konsekwencje. Rzecz jasna koncepcja CSR może i powinna być modyfikowana, pytanie tylko, czy eliminacja elementów zbliżających ją do etyki przekonań nie oznacza w gruncie rzeczy jej zarzucenia. 


\section{Typologia Webera}

Jak wiadomo, Weber nie zajmował się interesującą nas tu typologią zbyt systematycznie i rozróżnienie między „etyką przekonań” (Gesinnungsethik) a „etyką odpowiedzialności" (Verantwortungsethik) służyło przede wszystkim rozważeniu stosunków między etyką i polityką, a właściwie podkreśleniu swoistości etyki odpowiedniej dla oceny działań politycznych (Weber 1919/2011, s. 309). Co więcej, wykorzystujący to rozróżnienie wykład o polityce jako zawodzie i powołaniu (Politik als Beruf - 1919) mieści się w specyficznym kontekście rozliczeń po przegranej wojnie i „nowego otwarcia” w sytuacji ostrej walki politycznej. Z pewnością rozważania o relacjach etyki i polityki nie służyły więc tylko celom opisowym i nie jest całkiem jasne, czy chodzi o „głębokie przeciwieństwo” dwóch postaw etycznych (cf. s. 309) czy też o postawy w gruncie rzeczy komplementarne (s. 319).

Niemniej jednak rozróżnienie między „etyką przekonań” i „etyką odpowiedzialności" faktycznie wyraża istotną różnicę, zwłaszcza gdy potraktujemy je idealnotypologicznie. Jak dowiadujemy się z wykładu Webera, z etyką przekonań mamy do czynienia wówczas, gdy działanie kieruje się regułą bezwzględnej wierności wobec zasad uznanych za słuszne, niezależnie od treści tych przekonań. Bez względu na to, czy chodzi o etykę Kazania na Górze czy o „syndykalizm”, ważne jest konsekwentne trzymanie się przyjętych zasad, a nie skutki działań podjętych bądź niepodjętych w ich myśl. Trudność, na jaką w oczach Webera napotyka zastosowanie tak rozumianej etyki przekonań w polityce, wiąże się po pierwsze z tym, że działania podejmowane w myśl przekonań mogą przynosić skutki sprzeczne z przyjętymi wartościami: wynikiem kierowania się regułą niesprzeciwiania się złu może być - i często jest - potęgowanie owego zła. Po drugie, etyka przekonań staje przed problemem uświęcania środków przez cel, to znaczy musi „odrzucić każde działanie, które stosuje środki moralnie niebezpieczne” (Weber 1919/2011, s. 313). Jeśli charakterystycznym środkiem politycznym jest przemoc, to konsekwentny wyznawca etyki chrześcijańskiej właściwie nie może być skutecznym politykiem. Dlatego wzorcem etyki odpowiedzialności w polityce jest w oczach Webera Realpolitik, która z góry dopuszcza zastosowanie wątpliwych moralnie środków w imię wyższego celu. Jest to w gruncie rzeczy rozumowanie w kategoriach rachunku konsekwencji: mniejszego i większego zła, względnie mniejszego i większego dobra. Polityk - jak podkreśla Weber - jest odpowiedzialny również za zaniechanie podjęcia skutecznych działań w imię wierności zasadom.

Jak powiedziano, typologia Webera nie jest całkiem bez wad i stosunkowo łatwo doprowadzić ją do absurdu, wskazując, że przekonania, których konsekwentnie ma się trzymać polityk, mogą zawierać usprawiedliwienie dla wszelkiego rodzaju działań służących założonemu celowi, również stosowania przemocy na wielką skalę. Dlatego ważne jest dostrzeżenie, że działania według zasady wierności przekonaniom mogą zmierzać do tego samego celu, co działania w duchu Realpolitik i różnica dotyczy przede wszystkim stosunku do dopuszczal- 
nych środków ich osiągania. Ale chodzi też o kryterium oceny etyczności działań. Dlaczego właściwie w etyce przekonań tak ważne jest konsekwentne trzymanie się zasad, za którymi przecież nie stoją gwarancje słuszności? Dlatego, że zasady te są przez działającego uznawane za słuszne i kierowanie się nimi zaświadcza o czystości jego intencji.

Oznacza to, że etyka przekonań jest etyką skoncentrowaną na motywacji, zgodnie z wykładnią nadaną etyce ewangelicznej przez Kanta, który - jak wiadomo - za jedyną rzecz dobrą bez ograniczenia uznał „dobrą wolę” (1785/1984, s. 11). W tym świetle właściwe kryterium oceny działania stanowi jego intencja dochowania wierności zasadom uznanym za słuszne, czyli dobra wola ${ }^{1}$. Natomiast etyka odpowiedzialności wysuwa na pierwszy plan możliwe do przewidzenia lub prawdopodobne następstwa działania, a wówczas - bez względu na intencje - zasadniczą kwestią stają się jego rzeczywiste rezultaty, a także skuteczność. Zastosowanie odmiennych kryteriów oceny prowadzi często do sprzecznych wniosków: tak jak z punktu widzenia etyki odpowiedzialności poprzestawanie na dobrej woli może być karygodnym zaniechaniem, tak z punktu widzenia etyki przekonań podejrzane są również działania przynoszące pozytywnie oceniane rezultaty, o ile ich intencje nie były wystarczająco czyste.

Dochodzimy w ten sposób do punktu decydującego dla naszego tematu, to jest pytania o model etyki właściwy dla działań gospodarczych. A w sprawie tej należy zauważyć, że jako kwestia woli etyka przekonań rozgrywa się głównie w sferze prywatnej: dotyczy przekonań etycznych, które Weber uważał za (subiektywną) kwestię wyboru i decyzji, a co więcej rządzi się prywatną intencją dochowania wierności tej decyzji. Już z tego względu Weber twierdził, że należyte uwzględnienie swoistości działań politycznych - tak jak w przypadku etyki gospodarczej - musi brać pod uwagę konsekwencje działań i ich zaniechań, również te potencjalne. Dlatego etyka działań politycznych nie może poprzestawać na dobrej woli. Nasze pytanie brzmi: czy prywatna etyka intencji nadaje się do regulacji tego rodzaju stosunków społecznych, jak stosunki gospodarcze, zwłaszcza w warunkach konfliktu zasad, z jakim miał do czynienia Weber i z jakim mamy do czynienia obecnie.

\section{CSR jako etyka przekonań}

Jakie elementy zbliżają CSR do etyki przekonań? Z pewnością nie to, że przedsiębiorcy i menedżerowie z przekonania realizują cnoty ewangeliczne, nie traktując instrumentalnie swoich interesariuszy i kierując się intencją realizacji wspólnego dobra. Taki model dominuje jednak w dyskusjach o społecznej odpowiedzialności przedsiębiorstw i próbach jej standaryzacji - i tego zwykle domagają się od przed-

\footnotetext{
${ }^{1}$ Nie wchodzimy tu w żywo dyskutowaną kwestię, czy i w jakim stopniu ta obiegowa wykładnia jest trafną rekonstrukcją poglądu Kanta na temat kryteriów oceny działania (cf. na ten temat np. Höffe, 1995, s. 179 et seqq.). Dla naszych celów wystarczy wszak wysunięcie intencji na pierwszy plan, bez względu na to, czy jest to jedyny aspekt działania, jaki należy wziąć pod uwagę, czy nie.
} 
siębiorców i menedżerów koncepcje społecznej odpowiedzialności. Chociaż teoretycy CSR z reguły podkreślają, że warunkiem uznania działań firmy za społecznie odpowiedzialne jest efektywność ekonomiczna i przestrzeganie prawa, to w obiegowej opinii realizacja postulatów CSR ma wykraczać zarówno poza przestrzeganie prawa, jak i poza wykonywanie zwykłych działań firmy.

W istocie już w ,piramidzie Carrolla”, która miała duży wpływ na kształt dyskusji o CSR w ostatnich trzydziestu latach, tkwi założenie przesądzające o osobliwości pojęcia społecznej odpowiedzialności, o jakiej jest następnie mowa (cf. Carroll, 1991). A to dlatego, że etyczny aspekt społecznej odpowiedzialności nie tylko nie sprowadza się do odpowiedzialności za działania gospodarcze, ale jest przedstawiany $\mathrm{w}$ opozycji do tak rozumianej odpowiedzialności. Już to, że cztery rodzaje społecznej odpowiedzialności biznesu wyróżnione przez Carrolla (ekonomiczna, prawna, etyczna i filantropijna) tworzą hierarchię, przesuwa problem etyczności poza, ewentualnie ponad właściwą sferę działań firmy. Jak wiadomo, firma przede wszystkim ma być zyskowna (ekonomiczny aspekt odpowiedzialności), a dostarczając dóbr i usług ma spełniać wymogi prawa (prawny aspekt odpowiedzialności). Natomiast odpowiedzialność etyczna w ujęciu Carrolla, a tym bardziej filantropijna, wykracza poza przestrzeganie prawa i wiąże się ze wspieraniem sztuki i edukacji, uczestnictwem w działaniach charytatywnych i dobrowolnym wspomaganiu takich projektów, które podnoszą jakość życia lokalnej społeczności (1991, s. 41). Wprawdzie - jak zaznaczył Carroll - jego intencją nie była separacja wymienionych rodzajów odpowiedzialności, niemniej jednak jego piramida do takiej separacji prowadzi. Wynika $\mathrm{z}$ niej bowiem, że efektywne i zgodne z prawem działania gospodarcze z definicji nie mogą być uznawane za etyczne. Dlatego też w dyskusji na temat typów menedżerów i ich orientacji etycznych zarządzanie zorientowane na literę prawa określone zostaje jako zarządzanie amoralne (amoral management) (s. 45).

Ten sposób myślenia zdominował $\mathrm{w}$ ostatnich dziesięcioleciach dyskusję o społecznej odpowiedzialności korporacji, przedsiębiorstw i biznesu w ogóle (cf. np. Carroll \& Shabana, 2010, którzy istoty CSR upatrują w etycznych - w powyższym sensie - i filantropijnych zobowiązaniach korporacji wobec społeczeństwa). Jak zatem zwrócono uwagę, zarówno praktyka, jak i teoria CSR skoncentrowały się na „czynieniu dobra” (doing good), spychając na dalszy plan kwestię „unikania zła” (avoiding bad), to jest zapobiegania społecznej nieodpowiedzialności (cf. Lin-Hi \& Müller, 2013 i cytowana tam literatura, m.in. Campbell 2007; Lange, Washburn, 2012). Innymi słowy, nacisk na dobrowolność i pozytywność działań w zakresie CSR, ponadobowiązkowe przyczynianie się do podniesienia jakości życia i dobrobytu interesariuszy wyparł kwestię nieszkodzenia im. Tym samym jednak zwykłe pojęcie odpowiedzialności za ewentualne negatywne konsekwencje działań gospodarczych zostało rozpuszczone w etyce przekonań, kierowanej przez zobowiązanie firm do wnoszenia pozytywnego wkładu w realizację pożądanego ideału społecznego.

Chociaż wiadomo, że społeczna odpowiedzialność, o której mówią teoretycy i praktycy CSR, jest nader wieloznaczna i rozmaicie definiowana, to oba wyróżnione wątki specyfikacji programów CSR - dobrowolność i pozytywność - są na 
ogół traktowane jako kluczowe składniki ich charakterystyki. Wystarczy wskazać na znane standaryzacje CSR w rodzaju ISO 26000 oraz dokumenty Unii Europejskiej, która, jak wiadomo, przyjmuje hasła CSR jako ważny element swojej ideologii. I tak, zgodnie z informacjami zawartymi w „dobrowolnej Normie Międzynarodowej ISO 26000” (jak te „Wytyczne w sprawie odpowiedzialności społecznej" są określane w towarzyszących jej broszurach) standard ma wspomagać organizacje w przyczynianiu się do zrównoważonego rozwoju i zachęcać je do wykraczania poza przestrzeganie prawa, nawet jeśli zgodność z prawem jest podstawowym obowiązkiem każdej organizacji i istotną częścią jej społecznej odpowiedzialności (ISO 26000, 1). Wprawdzie definicja społecznej odpowiedzialności, jaką operują wytyczne ISO 26000, mówi o odpowiedzialności organizacji za skutki jej działań na społeczeństwo i środowisko, ma to jednak polegać na etycznych działaniach, które przyczyniają się do zrównoważonego rozwoju, w tym dobrobytu i zdrowia społeczeństwa (ISO 26000, 2.18). Chociaż wytyczne zapewniają, że społeczna odpowiedzialność powinna być integralną częścią strategii organizacyjnej, a filantropia nie powinna być substytutem dla takiej integracji (ISO 26000, 3.3.4), to rozwinięcie definicji społecznej odpowiedzialności akcentuje jej dobrowolny charakter: „The essential characteristic of social responsibility [...] is the willingness of an organization to incorporate social and environmental considerations in its decision making and be accountable for the impacts of its decisions and activities on society and the environment" (ISO 26000, 3.3.1, podkr. M.S.). Zgodnie z przytoczoną definicją społeczna odpowiedzialność polega więc na chceniu, co trzeba uznać za dość osobliwe pojęcie odpowiedzialności.

Podobnie kwestie te wyglądały w dokumentach UE dotyczących społecznej odpowiedzialności. W 2001 r. Komisja Europejska zdefiniowała społeczną odpowiedzialność przedsiębiorstw wprost jako „koncepcję, zgodnie z którą przedsiębiorstwa dobrowolnie uwzględniają problematykę społeczną i środowiskową w swojej działalności gospodarczej i stosunkach z zainteresowanymi stronami” (Komisja Europejska, 2001, s. 20). Jak przy tym podkreślono, „being socially responsible means not only fulfilling legal expectations, but also going beyond compliance and investing "more « into human capital, the environment and the relations with stakeholders" (Komisja Europejska, 2001, s. 21).

W dokumencie z 2006 r. CSR została określona jako „koncepcja, zgodnie z którą przedsiębiorstwa dobrowolnie uwzględniają problematykę społeczną i ekologiczną w swojej działalności komercyjnej i stosunkach z zainteresowanymi stronami”, przy czym „,zgodnie z tą koncepcją przedsiębiorstwa decydują się wykroczyć poza minimalne wymogi prawne i zobowiązania wynikające z układów zbiorowych w celu uwzględnienia potrzeb społecznych" (Komisja Europejska, 2006, s. 2). Warto zauważyć, że w tym dokumencie dobrowolność CSR uzyskała nie tylko oficjalne potwierdzenie, ale i uzasadnienie. Mianowicie:

Ponieważ CSR opiera się przede wszystkim na dobrowolnej postawie przedsiębiorstw, podejście, przy którym na przedsiębiorstwa zostałyby nałożone dodatkowe obowiązki i wymogi administracyjne, miałoby najprawdopodobniej przeciwny skutek i byłoby sprzeczne z zasadami lepszych uregulowań prawnych. (Komisja Europejska, 2006, s. 2-3) 
Jak wiadomo, w 2011 r., po wybuchu kryzysu finansowego, w „Odnowionej strategii UE na lata 2011-2014 dotyczącej społecznej odpowiedzialności przedsiębiorstw” komisja sformułowała „nową” definicję CSR, przedstawiając ją jako „odpowiedzialność przedsiębiorstw za ich wpływ na społeczeństwo”, gdzie „poszanowanie dla mającego zastosowanie prawodawstwa [...] jest warunkiem wstępnym wypełniania zobowiązań wynikających z tej odpowiedzialności” (Komisja Europejska, 2011). Jak widać, w tej ostatniej, nadal obowiązującej definicji nie mówi się już o dobrowolności, nie znaczy to jednak, że implementacja postulatów CSR stała się prawnym obowiązkiem, względnie że zmieniło się ujęcie CSR jako wkładu $\mathrm{w}$ dzieło społecznego postępu. Wynikiem pokryzysowej refleksji było bowiem zaplanowanie inicjatyw w zasadzie nienaruszających reguły dobrowolności. Zaplanowano więc m.in. (Komisja Europejska, 2011, s. 11-12):

(1) utworzenie ,wielostronnych platform [...], których celem będzie publiczne zobowiązanie się przedsiębiorstw, ich pracowników i innych zainteresowanych stron w kwestiach CSR mających znaczenie dla każdego sektora oraz zapewnienie wspólnego monitorowania postępów”;

(2) „otwartą debatę z udziałem obywateli, przedsiębiorstw i innych zainteresowanych stron na temat roli i potencjału przedsiębiorstw w XXI wieku";

(3) ,europejski program nagród dla partnerstw CSR między przedsiębiorstwami a innymi zainteresowanymi stronami";

(4) „opracowanie kodeksu dobrych praktyk w zakresie samo- i współregulacji, który powinien przyczynić się do poprawy skuteczności procesu CSR".

Reakcja komisji na nadużycia związane $\mathrm{z}$ traktowaniem programów CSR jako narzędzia wizerunkowego ograniczała się zatem głównie do zaplanowania działań promocyjnych i edukacyjnych. Chyba najbardziej konkretną sprawą, jaką zajęła się komisja, była kwestia wprowadzającej w błąd reklamy związanej z oddziaływaniem produktów na środowisko (tzw. green-washing). Kolejnym efektem prac komisji była również dyrektywa Parlamentu Europejskiego w sprawie ujawniania informacji niefinansowych przez duże przedsiębiorstwa i w konsekwencji wprowadzenie obowiązku - również w Polsce - raportowania działań z zakresu CSR dla firm zatrudniających powyżej 500 pracowników. Rzecz jasna obowiązek raportowania nie zmienia dobrowolnego i pozytywnego charakteru CSR i nic dziwnego, że większość „dobrych praktyk" z zakresu CSR - również w Polsce - dotyczy działań o charakterze sponsorskim, charytatywnym i edukacyjnym (cf. Forum Odpowiedzialnego Biznesu, 2018). Realizuje się w ten sposób dominujący model rozumienia społecznej odpowiedzialności.

\section{Uwagi krytyczne}

Elementem zbliżającym CSR do etyki przekonań jest zatem „dobrowolna pozytywność" - założenie, że podjęcie społecznej odpowiedzialności oznacza dobrowolną realizację działań wykraczających poza zwykłe działania firmy i stanowią- 
cych jej specjalny wkład w przekształcanie stosunków społecznych zgodnie z wzorem, który uznany został za stan pożądany. Skoro reguła wierności zasadom budzi na ogół całkiem pozytywne skojarzenia, to nie ma powodu, by uważać, że źródłem kłopotów z CSR jest sam model etyki przekonań, który - jak zresztą zauważył Weber - bez wątpienia w pewnych zastosowaniach jest całkowicie na miejscu. Dlaczego zatem wzorowanie implementacji etyki w sferze biznesu na etyce przekonań może budzić poważne wątpliwości? Zwięzła odpowiedź brzmi: ponieważ ten sposób implementacji nie uwzględnia specyfiki działań gospodarczych, przez co rozmywa właściwe tej sferze pojęcie odpowiedzialności. Sprywatyzowanie etyczności do sfery intencji nie pozwala na właściwe ujęcie relacji między etyką i prawem, a w końcu sprzyja organizacyjnej hipokryzji, rozumianej jako jaskrawe rozmijanie się etycznych deklaracji i rzeczywistych działań przedsiębiorstw.

Zwróćmy po pierwsze uwagę na konsekwencje określenia społecznej odpowiedzialności przedsiębiorstw jako działań wykraczających poza zwykłe działania firmy i przyczyniających się do „zrównoważonego rozwoju”, względnie społecznego dobrobytu. Jest jasne, że ten sposób rozumienia społecznej odpowiedzialności jest zabiegiem zmieniającym znaczenie słowa odpowiedzialność i oznacza przesunięcie, względnie rozszerzenie jej zakresu na bliżej niesprecyzowany całokształt stosunków społecznych. Zabieg ten jest skądinąd powodem charakterystycznej nieokreśloności koncepcji CSR, która - jak się często wskazuje - posiada wiele znaczeń i jest na tyle rozmaicie rozumiana, że nie jest wcale jasne nawet to, za co, przed kim i w jakim zakresie odpowiada przedsiębiorstwo (cf. np. Van Marrewijk, 2003; Lockett, Moon \& Visser, 2006; Matten \& Moon, 2008).

Tymczasem, jeśli (z definicji) odpowiedzialność dotyczy przede wszystkim intencjonalnych działań, a przedsiębiorstwo jest organizacją podejmującą działania gospodarcze, to zwykłe pojęcie odpowiedzialności przedsiębiorstwa dotyczy jego działań gospodarczych, to jest sprzedaży towarów bądź usług, a szerzej maksymalizowania wartości, która jest jego celem. Nawet jeśli wbrew liberalnej definicji biznesu (cf. Sternberg, 1998, s. 50) uznamy, że firma odpowiada nie tylko wobec właścicieli, ale również wobec innych interesariuszy, to nadal nie wynika z tego, iż przedsiębiorstwo odpowiada za coś innego niż podejmowane działania i ich ewentualne skutki uboczne. Możemy zatem przyjąć, że firma odpowiada nie tylko za swoje działania, ale również za sposób, w jaki realizuje swój cel: w tym sensie jest odpowiedzialna wobec interesariuszy wewnętrznych i zewnętrznych, na przykład pracowników i klientów, a także odpowiada za środowiskowe skutki swoich działań. Nie znaczy to jednak, że firma odpowiada i powinna odpowiadać za coś, do czego może się przyczyniać co najwyżej pośrednio i co z punktu widzenia pojedynczego przedsiębiorstwa jest abstrakcją: za zrównoważony rozwój lub społeczny dobrobyt. Równie niejasna, jak treść pojęcia odpowiedzialności, staje się bowiem wówczas kwestia tego, przed kim firma odpowiada za swoje działania, skoro zamiast skonkretyzowanych interesariuszy pojawia się abstrakcyjnie rozumiane społeczeństwo. Jeśli zatem według postulatów CSR firma jest odpowiedzialna za społeczny dobrobyt przynajmniej w tym sensie, że powinna się 
do niego przyczyniać, to specyficznie rozumiana pozytywność CSR rozmywa pojęcie odpowiedzialności za działania gospodarcze.

Po drugie, krytycznej analizy domaga się charakterystyczny dla CSR element dobrowolności, to znaczy wymagania, by uczestnicy życia gospodarczego chcieli wypełniać postulaty tej koncepcji i przez to realizowali zasady społecznej odpowiedzialności. A w sprawie tej należy zauważyć, że oparcie etyki biznesu na pojęciu dobrej woli uzależnia ocenę działań gospodarczych od czegoś, co z reguły nie jest dla niej istotne. Klientowi jest bowiem w zasadzie obojętne, jakie motywy kierują sprzedawcą towarów lub usług, skoro i tak nie może nic pewnego na ten temat wiedzieć ${ }^{2}$. Niezależnie od tego, czy sprzedawca kieruje się chęcią zysku czy też dobrą wolą, względnie swoimi wyobrażeniami na ten temat, chodzi więc o uczciwą transakcję, której reguły są całkiem dobrze określone i nie mogą zależeć od widzimisię sprzedawcy. Klient kupujący prezerwatywy nie oczekuje od sprzedawcy, że zgodnie z jego przekonaniami religijnymi towar zostanie podziurkowany. Ale $-\mathrm{z}$ drugiej strony - konserwatywny użytkownik wyszukiwarki internetowej będzie uważał za nadużycie jego zaufania preferowanie w wynikach zapytań stron oferujących ,postępowe” treści. W obu przypadkach złamano zasadę dostarczenia towaru bądź usługi zgodnie z oczekiwaną specyfikacją, w imię przekonań uznanych za słuszne przez dostawcę. W obu przypadkach z punktu widzenia klienta jest to działanie nieetyczne.

W sprawie modelu etyki przyjętego na potrzeby CSR najważniejsze jest zatem to, że etyka przekonań jest etyką pierwszoosobową, to znaczy wyznacza postawę jednostki z punktu widzenia jej przekonań wobec tego, co dla niej zewnętrzne. W tego rodzaju zsubiektywizowanej etyce prawidłowe jest to, co się wydaje prawidłowe, w tym sensie etyka przekonań jest etyką prywatną. Ten model pierwszoosobowej etyki nie jest właściwy dla etyki biznesu, ponieważ stosunki gospodarcze są stosunkami par excellence społecznymi, wymagającymi intersubiektywnych uzgodnień. Pierwszoosobowy punkt widzenia uzależnia ocenę (a po części i kształt) stosunków społecznych od zmiennego widzimisię ich dominującego podmiotu. Tymczasem efektywna regulacja stosunków społecznych musi mieć charakter zobiektywizowany, co może być osiągnięte nie tylko przez odwołanie się do niezależnej instancji, ale i przez milczące porozumienie. Nawiązujemy w ten sposób rzecz jasna do wyników dociekań Wittgensteina dotyczących kierowania się regułą i prywatnego języka: kierowanie się regułą nie może mieć charakteru wyboru czy interpretacji, gdyż prowadzi to do paradoksu, w którym każdy sposób działania dawałby się uzgodnić z regułą. A sądzić, że kierujemy się regułą, byłoby tym samym, co kierować się regułą (Wittgenstein, 1958/1972, par. 198-202). Jest to ujęcie w ważnym punkcie przeciwstawne w stosunku do Kantowskiej tradycji etyki intencji, w której mieści się również etyka przekonań. Etyka biznesu nie może poprzestawać na tej tradycji, ponieważ ważne jest dla niej to, co podmioty gospodarcze faktycznie robią (a także konsekwencje tego, co robią), a nie to, czy chca działać etycznie.

\footnotetext{
2 Jest nader charakterystyczne, że po wybuchu afery spalinowej, jak donosiła prasa, sprzedaż samochodów Volkswagena w Polsce wzrosła, a nie spadła. Z punktu widzenia postulatów CSR nie jest to, rzecz jasna, przejaw racjonalnej kalkulacji, ale konsumenckiej niedojrzałości naszego rynku.
} 
Po trzecie zwróćmy uwagę, że pokrewieństwo z etyką przekonań i intencji narzuca koncepcji CSR wadliwe ujęcie relacji między etyką i prawem. Jest to ujęcie, zgodnie z którym etyczne działanie nie może polegać na zgodności z prawem, ale musi spełniać dodatkowy warunek autotelicznego ukierunkowania, zatem wykazywać się dobrowolnością (nawiasem mówiąc, Kant wprawdzie twierdził, że jedynie dobra wola jest dobra bez ograniczenia, ale nie znaczy to przecież, że dobre - chociaż z pewnymi ograniczeniami - nie mogą być również inne rzeczy). W istocie w ślad za Carrollem większość teoretyków CSR uważa, że społeczna odpowiedzialność przedsiębiorstw zachodzi w sferze ponadprawnej dobrowolności, często traktowanej w opozycji do zwykłego przestrzegania prawa (cf. np. Berger-Walliser \& Scott, 2018 i komentarz w Soin, 2018). Oznacza to jednak, że działania zgodne z prawem z definicji nie mogą być uważane za etyczne, co jednak jest przekonaniem wynikającym z doktrynalnego zastosowania kryterium dobrowolności w ocenie etycznej, ponadto prowadzącym do szczególnego paradoksu: mianowicie jeśli wymagania etyczne, na przykład dotyczące zgodnego z prawdą informowania o sprzedawanym towarze bądź usłudze, zostaną wprowadzone do obowiązującego systemu prawnego, to działania uważane dotąd za etyczne przestają nimi być na skutek reformy prawa.

Konkurencyjny obraz relacji między etyką i prawem nie przeciwstawia więc tych dziedzin, ale przeciwnie, regulacje prawne może traktować jako narzędzie etyki (cf. np. Ostas, 2001). Jest to możliwe dzięki rezygnacji z zastosowania kryterium intencji jako podstawy oceny etycznej. Jeśli kryterium tym nie jest motywacja, ale zgodność z regułą, to wprowadzenie prawnych wymagań dotyczących działalności gospodarczej (ale także każdej innej) oznacza tylko i aż dalszą instytucjonalizację zasad, które do tej pory miały charakter zwyczajowych postulatów. Należy jednak zauważyć, że wraz z tym ujęciem zmienia się treść pojęcia społecznej odpowiedzialności przedsiębiorstw, która przestaje wiązać się z nieokreślonym wkładem do społecznego dobrobytu, ale staje się skonkretyzowaną odpowiedzialnością firmy wobec jej interesariuszy za podejmowane przez nią działania gospodarcze. Dopiero ten powrót do zwykłego pojęcia odpowiedzialności likwiduje rzekomą separację między etyką i biznesem, która jest efektem nakładania na przedsiębiorstwa zadań, które do nich nie należą. W tym sensie źródłem kłopotów z CSR jest nieuwzględnianie specyfiki działań gospodarczych, posiadających wszak dobrze określony cel ekonomiczny. Narzucenie modelu etyki przekonań na działalność gospodarczą jest w gruncie rzeczy próbą zmiany jej definicji. Jeśli jednak nie jest to cel przypadkowy, to trudno się dziwić, że wynikiem nacisku na realizację postulatów CSR jest organizacyjna hipokryzja.

Dobrowolna pozytywność nie tylko nie służy więc implementacji postulatów etycznych w biznesie, ale wręcz sprzyja rozmijaniu się deklaracji o podejmowaniu społecznej odpowiedzialności z praktyką gospodarczą firm. Dodajmy, że wskazane wady koncepcji CSR skłaniały do jej różnie ukierunkowanych reform, zmniejszających podatność tej koncepcji na nadużycia (Soin, 2018). Na przykład Aguinis i Glavas (2013) rozróżnili „zintegrowany” (embedded) i „,peryferyjny” (peripheral) CSR, twierdząc że tylko ,integracja” CSR polegająca na powiązaniu postulatów prospołecznych i proekologicznych z głównym obszarem działań i kompeten- 
cji firmy jest finansowo korzystna dla przedsiębiorstw podejmujących działania z zakresu społecznej odpowiedzialności. Jednakże, chociaż taki zabieg pozwala wykluczyć z zakresu społecznej odpowiedzialności jej najbardziej krytykowane formy, mianowicie sponsoring i korporacyjną filantropię, to jasne jest, że jego zastosowanie jest ograniczone do tych firm, które działalność prospołeczną i proekologiczną mogą uczynić głównym obszarem swych działań i kompetencji. Model zintegrowanego CSR nadaje się zatem tylko do nielicznych branż (na przykład do produkcji ekologicznych pieców), jawnie nie odpowiadając tym, w których działalność gospodarcza nie przekłada się bezpośrednio na efekty pozagospodarcze. Ale skoro ich działalność polega na dostarczaniu dóbr i usług, na które jest popyt, to ich odpowiedzialność musi dotyczyć właśnie tych działań.

\section{Konkluzja}

Koncepcja społecznej odpowiedzialności przedsiębiorstw miała być sposobem implementacji postulatów etycznych w biznesie. Jest jednak wątpliwe, czy może ona spełnić tak postawione zadanie, jeśli sednem CSR w obiegowym rozumieniu stała się „dobrowolna pozytywność”, to znaczy koncentracja na intencjonalnym czynieniu dobra. Jest tak z co najmniej kilku względów.

Po pierwsze, ze względu na niejasność pojęcia „społecznej odpowiedzialności”, która stała się odpowiedzialnością za abstrakcyjne dobro abstrakcyjnie rozumianego społeczeństwa. Jeśli „społecznie odpowiedzialna” firma nie tylko może, ale wręcz powinna na własną rękę określić, na czym polega jej wkład w realizację postulatów CSR, to tym samym zamiast odpowiedzialności przedsiębiorstwa za jego działania gospodarcze podstawiony zostaje konstrukt pozbawiony treści i podlegający w zasadzie dowolnej interpretacji.

Po drugie, ze względu na prywatny charakter reguł postulowanych w CSR, odsyłający do tradycji definiowania etyczności przez dobrą wolę. To pierwszoosobowe ujęcie etyki nie nadaje się do implementacji postulatów etycznych w biznesie już z tego względu, że stosunki gospodarcze są stosunkami społecznymi i ich ocena wymaga uwzględnienia punktu widzenia interesariuszy firmy. Dlatego ważniejsze niż intencje i deklaracje firmy są jej rzeczywiste działania i ich konsekwencje.

Po trzecie, ze względu na model relacji między etyką i prawem narzucany przez oparcie CSR na tradycji etyki intencji. Uzależnienie oceny etycznej od intencji przeciwstawia działania zgodne z prawem i działania etyczne, nie pozwalając na uznanie regulacji prawnych za instrument etyki. W efekcie zatem, rozmywając pojęcia dobra i odpowiedzialności, dominujące rozumienie idei CSR utrudnia instruktywną dyskusję etyczną o działalności gospodarczej. Jeśli głównym kryterium etyczności jest dobra wola, to zwykłe działania gospodarcze - jako motywowane zyskiem - nie mogą być przedstawiane jako etyczne już ze względów definicyjnych. W konsekwencji etyka całkowicie rozmija się z działalnością 
gospodarczą, co oznacza, że koncepcja CSR pogłębia, a nie znosi separację etyki i biznesu.

W zasadzie nie powinno zatem dziwić, że społeczna odpowiedzialność przedsiębiorstw zarówno przez teoretyków, jak i praktyków CSR traktowana jest coraz częściej jako problem wizerunkowy. Chociaż skala organizacyjnej hipokryzji skłoniła bardziej wnikliwych badaczy do zajęcia się kwestią, to nie jest wcale powszechnie przyjęte, że rozwiązanie tego problemu wymaga dość radykalnej zmiany sposobu rozumienia idei społecznej odpowiedzialności przedsiębiorstw. Jeśli w podsumowaniu można zatem stwierdzić, że - paradoksalnie - powiązanie CSR z wzorem etyki przekonań raczej oddala niż przybliża implementację etyki w działalności gospodarczej, to trzeba też zwrócić uwagę na podwójny charakter tego paradoksu. Z jednej bowiem strony CSR wiąże się z wzorcem etyki przekonań tym, czego się domaga od odpowiedzialnych przedsiębiorców: dobrowolnej realizacji działań prospołecznych, wykraczających poza działania gospodarcze. $\mathrm{Z}$ drugiej jednak strony można stwierdzić, że teoretyczna dyskusja wokół CSR w znacznej mierze przebiega według wzoru etyki przekonań. Przeciętny autor tekstu o społecznej odpowiedzialności przedsiębiorstw ma zatem wiele do powiedzenia o sposobach raportowania dokonań firmy w tym zakresie, względnie o zaletach, jakie przynosi wdrażanie CSR, ale nie dba z reguły o konsekwencje rozpowszechnianej przez siebie koncepcji. Pomija więc w szczególności łatwy do stwierdzenia rozziew między deklaracjami w zakresie CSR i faktycznymi działaniami firm, generowany - między innymi - przez „dobrowolną pozytywność”. Znaczy to jednak w najlepszym razie, że sam kieruje się wzorem takiej etyki światopoglądowych przekonań, w której deklaracje i działania stanowią odrębne sfery.

Pozwala to nieco inaczej niż się ostatnio przyjęło potraktować krytyczne wypowiedzi o CSR Friedmana i jego zwolenników, które uważa się zwykle za zdezaktualizowane przeżytki ekonomicznego (neo)liberalizmu. Chociaż trudno byłoby obecnie bronić tezy redukującej społeczną odpowiedzialność menedżerów spółki do odpowiedzialności wobec jej właścicieli, a zatem akcjonariuszy, to trzeba zwrócić uwagę, że krytyka rozszerzania społecznej odpowiedzialności menedżerów była $\mathrm{w}$ istocie obroną swoistości działalności gospodarczej, wraz z ukierunkowaniem na zysk jako jej konstytutywną cechę. Jak pamiętamy, podobne były motywacje typologii Webera, który domagał się uwzględnienia swoistości sytuacji etycznej polityka ocenianego wszak między innymi z punktu widzenia skuteczności. Zestawienie problemów CSR z typologią Webera pozwala zatem uwydatnić specyfikę etycznej oceny działań gospodarczych. A w tym świetle zadaniem etyki biznesu nie jest przeobrażenie przedsiębiorców i menedżerów w prospołecznych aktywistów, ale skuteczna implementacja postulatów etycznych w relacjach firmy $\mathrm{z}$ jej interesariuszami. Podstawowym środkiem tego rodzaju działań są zaś regulacje prawne, o czym można się przekonać na przykładzie sukcesów w zakresie prawa pracy, uprawnień konsumenckich, a także ochrony środowiska. 


\section{Bibliografia}

Aguinis, H., \& Glavas, A. (2013). Embedded versus peripheral corporate social responsibility: Psychological foundations. Industrial and Organizational Psychology, 6, 314-332.

Berger-Walliser, G., \& Scott, I. (2018). Redefining corporate social responsibility in an era of globalization and regulatory hardening. American Business Law Journal, 55(1), 167-218.

Campbell, J. L. (2007). Why would corporations behave in socially responsible ways? An institutional theory of corporate social responsibility. Academy of Management Review, 32(3), 946-967.

Carroll, A. B. (1991). The pyramid of corporate social responsibility: Toward the moral management of organizational stakeholders. Business Horizons, 34(4), 39-48.

Carroll, A. B., \& Shabana, K. M. (2010). The business case for corporate social responsibility: A review of concepts, research and practice. International Journal of Management Reviews, 12(1), 85-105.

Fassin, Y., \& Buelens, M. (2011). The hypocrisy-sincerity continuum in corporate communication and decision making: A model of corporate social responsibility and business ethics practices. Management Decision, 49(4), 586-600.

Forum Odpowiedzialnego Biznesu. (2018). Raport Odpowiedzialny biznes w Polsce. Dobre praktyki. https://odpowiedzialnybiznes.pl/publikacje/raport-2018

Höffe, O. (1995). Immanuel Kant (M. Kaniowski, tłum.). Warszawa: Wydawnictwo Naukowe PWN.

ISO 26000. (2010). International Standard Guidance on social responsibility. https://www.iso.org/iso-26000-social-responsibility.html

Jahdi, K. S., \& Acikdilli, G. (2009). Marketing communications and corporate social responsibility (CSR): Marriage of convenience or shotgun wedding? Journal of Business Ethics, 88(1), 103-113.

Kant, I. (1785/1984). Uzasadnienie metafizyki moralności (M. Wartenberg, thum.). Warszawa: Państwowe Wydawnictwo Naukowe.

Komisja Europejska. (2001). Promoting a European framework for Corporate Social Responsibility. http://ec.europa.eu/transparency/regdoc/rep/1/2001/ EN/1-2001-366-EN-F1-1.Pdf

Komisja Europejska. (2006). Realizacja partnerstwa na rzecz wzrostu gospodarczego i zatrudnienia: uczynienie Europy liderem w zakresie odpowiedzialności społecznej przedsiębiorstw. https://eur-lex.europa.eu/LexUriServ/ LexUriServ.do?uri=COM:2006:0136:FIN:PL:PDF

Komisja Europejska. (2011). Odnowiona strategia UE na lata 2011-2014 dotycząca społecznej odpowiedzialności przedsiębiorstw. http://ec.europa.eu/trans parency/regdoc/rep/1/2011/PL/1-2011-681-PL-F1-1.Pdf 
Lange, D., \& Washburn, N. T. (2012). Understanding attributions of corporate social irresponsibility. Academy of Management Review, 37(2), 300-326.

Lin-Hi, N., \& Müller, K. (2013). The CSR bottom line: Preventing corporate social irresponsibility. Journal of Business Research, 66(10), 1928-1936.

Lockett, A., Moon, J., \& Visser, W. (2006). Corporate Social Responsibility in management research: focus, nature, salience and sources of influence. Journal of Management Studies, 43(1), 115-136.

Matten, D., \& Moon, J. (2008). "Implicit" and "Explicit" CSR: A conceptual framework for a comparative understanding of corporate social responsibility. Academy of Management Review, 33(2), 404-424.

Ostas, D. T. (2001). Deconstructing corporate social responsibility: Insights from legal and economic theory. American Business Law Journal, 38(2), 261-299.

Sikka, P. (2010). Smoke and mirrors: Corporate social responsibility and tax avoidance. Accounting Forum, 34(3), 153-168.

Soin, M. (2018). CSR i problem organizacyjnej hipokryzji. Prakseologia, 160, 223-241.

Sternberg, E. (1998). Czysty biznes. Etyka biznesu w działaniu (P. Łuków, tłum). Warszawa: Wydawnictwo Naukowe PWN.

Van Marrewijk, M. (2003). Concepts and definitions of CSR and corporate sustainability: Between agency and communion. Journal of Business Ethics, 44(2-3), 95-105.

Weber, M. (1919/2011). Polityka jako zawód i powołanie (A. Kopacki, tłum.). W: M. Weber, Racjonalność, władza, odczarowanie (red. M. Holona). Poznań: Wydawnictwo Poznańskie.

Wittgenstein, L. (1958/1972). Dociekania filozoficzne (B. Wolniewicz, tłum). Warszawa: Państwowe Wydawnictwo Naukowe. 